\title{
GCU
}

Glasgow Caledonian

University

University for the Common Good

\section{Empowering communities? Exploring roles in facilitated social enterprise}

Finlayson, Eilidh; Roy, Michael

Published in:

Social Enterprise Journal

DOI:

10.1108/SEJ-04-2018-0035

Publication date:

2019

Document Version

Author accepted manuscript

Link to publication in ResearchOnline

Citation for published version (Harvard):

Finlayson, E \& Roy, M 2019, 'Empowering communities? Exploring roles in facilitated social enterprise', Social Enterprise Journal, vol. 15, no. 1, pp. 76-93. https://doi.org/10.1108/SEJ-04-2018-0035

\section{General rights}

Copyright and moral rights for the publications made accessible in the public portal are retained by the authors and/or other copyright owners and it is a condition of accessing publications that users recognise and abide by the legal requirements associated with these rights.

Take down policy

If you believe that this document breaches copyright please view our takedown policy at https://edshare.gcu.ac.uk/id/eprint/5179 for details of how to contact us. 


\title{
Empowering Communities? Exploring Roles in Facilitated Social Enterprise
}

\author{
Eilidh Finlayson and Michael J. Roy \\ Yunus Centre for Social Business and Health \\ Glasgow Caledonian University \\ Glasgow, UK \\ Corresponding Author: eilidh.finlayson@gcu.ac.uk
}

\section{Authors' Pre-Publication Version}

Cite as:

Finlayson, E and Roy, M.J. (2018), Empowering Communities? Exploring Roles in Facilitated Social Enterprise, Social Enterprise Journal 14(3) 


\title{
EMPOWERING COMMUNITIES?
}

\section{EXPLORING ROLES IN FACILITATED SOCIAL ENTERPRISE}

\author{
Abstract
}

\section{Purpose:}

States and development bodies are increasingly stimulating social enterprise activity in communities as an empowering social and economic development intervention. This type of development initiative is often facilitated by actors who are external to communities, and the role of community members is not clear. This paper explores whether facilitated social enterprise benefits or disempowers communities.

\section{Design/Methodology/Approach:}

The focus is a case study of a project based in Scotland designed to stimulate the creation of social enterprises involved in community growing. The case study approach involved a mix of methods, including formal (semi-structured) interviews, participant observation, and analysis of documentary evidence. Analysis of findings was undertaken using Muñoz and Steinerowski’s (2012) theory of social entrepreneurial behaviour.

\section{Findings:}

Findings suggest that social enterprise that originates outside communities and is facilitated by external actors is potentially disempowering, particularly when social enterprise development does not necessarily align with community needs. The paper reiterates findings in previous studies that certain roles in facilitated social enterprise require to be community-led. Projects that do attempt to facilitate social enterprise would benefit from community participation at the project planning stage.

Keywords: Social Enterprise, empowerment, stakeholder roles, community development. 


\section{Introduction}

Social enterprise is widely understood as a means to provide "creative solutions to complex and persistent social problems" (Zahra et al., 2009: 519), and there is support for the idea that social enterprise can be empowering. Social enterprises can help excluded groups overcome economic and cultural exclusion (Al-Dajani and Marlow, 2013; Defourny and Nyssens, 2008; Reynolds, 2008) and, for some commentators, social enterprise is "a mechanism for community empowerment" (Scottish Government, 2016: 4). Collective or 'community-led' social enterprise (Haugh, 2007) offers "a new strategy for people-centred local economic development" (Gibson and The Community Economies Collective, 2013: 84) and conceptualises community members as 'assets' that can be mobilised for development purposes. In doing so, community social enterprise is thought to represent the democratisation of development by devolving power to communities.

There is, however, little evidence to suggest that introducing social enterprise from outside is necessarily beneficial or empowering for communities (see, for example, Dart, 2004; Eikenberry and Kluver, 2004 around some of the risks to civil society in general). Not all communities possess the skills required to deliver social enterprise and in some communities professionals are deployed to facilitate the process, as seen in the example of the European project which introduced the concept of social enterprise to communities and then sought to test the extent to which community social enterprise can be facilitated (Farmer et al., 2012). In such scenarios, development agencies and the wider public sector work to 'externally stimulate' (Haugh, 2007) social enterprise activity, with external actors undertaking key roles within the social enterprise development process to complement the skills and talents of individuals who are 'endogenous' to communities and organisations. As Steiner and Farmer (2017) suggest: when external agencies initiate development activities, there is a risk that development is done on the terms of the development agency. So development is 'done to' communities rather than 'done by' communities. When external actors facilitate social enterprise development and undertake key activities within this process, it is not clear how much this type of social enterprise contributes to empowering communities. This begs the research question: does facilitated social enterprise benefit or disempower communities? 
Our paper draws on research carried out in Scotland and employs Muñoz and Steinerowski's (2012) theory of social entrepreneurial behaviour to unpack the roles of various actors involved in the development of a social enterprise. In so doing, the paper addresses questions around which actors are participating in the activities involved in community social enterprise development when social enterprise is facilitated by external actors, and the degree to which it can be considered empowering. The paper is organised as follows: firstly, an overview of the role of individuals and communities in social enterprise development is provided, along with an explanation of community social enterprise as a development tool and theoretical perspectives which serve to problematize this concept. We then introduce the case and contextual information before presenting the perceptions of the people involved in the Project. The paper concludes with a consideration of the implications of findings for policy, practice and theory.

\section{Individuals and Communities in Social Enterprise}

There has long been an identified tension between individual and collective action in social enterprise. One dominant narrative in the extant social entrepreneurship literature relates to the skills and abilities of individuals to address social aims (Dees, 1998; Leadbeater, 1997; Martin and Osberg, 2007; Smith et al., 2014), and presents the social entrepreneur as a 'heroic' agent of social change (Drayton, 2011) with unique personal characteristics - such as creativity and drive - which enable them to identify social needs, generate new ideas and recognise opportunities (Peredo and McLean, 2006). Accordingly, much support for social enterprise has focused on developing the ideas and skills of individuals (Nicholls, 2010; Seanor and Meaton, 2008). Critics of the individual action perspective note that a tendency to focus attention primarily on the role of the individual in social enterprise development can lead to a "neglect of established sociological knowledge about community-oriented development processes" (Jackson et al., 2018; see also Dart, 2004). Research shows that social networks allow individuals involved in social enterprise to access the knowledge and skills of others, as well as financial and nonfinancial support (Corner and Ho, 2010; Sonne, 2015; Steiner and Teasdale, 2016), and that individuals must work to gain legitimacy for their social enterprises so that they can access resources, mobilise stakeholders and gain social acceptance (Di Domenico et al., 2010; Ruebottom, 2013). From a collective 
action perspective, it is collaboration between individuals that drives social enterprise development (Corner and Ho, 2010; Fletcher, 2006; Montgomery et al., 2012) and the term 'community social enterprise' has come to be used to refer to groups collaborating to solve an unmet need in their community through social enterprise. Thus, social enterprise emerges as a collaborative activity that relies strongly on the skills of a variety of individuals.

Research has sought to clarify the skills required for community social enterprise. In keeping with entrepreneurship theory (Chell, 2013), community social enterprise is understood as a process comprising sequential activities of 'needs identification', 'opportunity recognition', 'idea generation' and 'idea exploitation' (Haugh, 2007; Muñoz et al., 2014). Within these activities, researchers have been able to posit a theory of social entrepreneurial behaviour. Muñoz and Steinerowski (2012) conducted a comprehensive review of typologies of social entrepreneurial behaviour in the existing literature to identify three overarching capability domains of opportunism, leadership and networking. The authors then explored narratives from a four-year project which stimulated the creation of 11 community social enterprises across five EU countries to map how social entrepreneurial skills are used in the development of social organisations (2012). Muñoz and Steinerowski's (2012) approach provides an empirically grounded theoretical framework within which the skills and activities of individuals operating in collective social enterprise can be understood.

Research has also shown that when community social enterprise is initiated and facilitated by external actors, certain activities must be community-led or they are highly unlikely to be successful. In Muñoz and Steinerowski's (2012) study, Project Managers facilitated the community social enterprise development process, and often suggested a socially entrepreneurial solution to social problems. However, it was essential to the success of community social enterprise that community members identified the social need in the first place and established a social mission (2012). Reporting from the same study, Muñoz et al. (2014) agree that while community social enterprise relied strongly on the leadership of Project Managers, it was important that key individuals within the community were mobilised. These findings echo Haugh (2007), who suggests that although the need for a community social enterprise can be stimulated by actors inside or outside the community, it is absolutely necessary 
that members of the community take ownership of the problem to be addressed and initiate action. If these activities did not happen or were not community-led, the project might fail to gain legitimacy within the community and the community might experience a lack of ownership for the project (Haugh, 2007; Muñoz et al., 2014). Ultimately, a project without ownership and legitimacy in the community would be expected to fail. There is therefore a tension between the roles of external actors and community members in facilitated social enterprise which must be managed carefully to ensure community ownership of the venture. This tension is important within the context of increased devolution of power to communities in Scotland and the promotion of social enterprise as a tool for development.

\section{Social Enterprise as a Development Tool}

Stimulating social enterprise activity within communities has become a mainstream yet contentious social and economic development activity undertaken by a range of policy actors. One example is when Non-Governmental Organisations piloted an action research intervention in the Philippines to promote community experimentation with collective enterprise (Gibson and The Community Economies Collective, 2013), while in Europe a similar style of project introduced the concept of social enterprise to communities and sought to test the extent to which community social enterprise can be facilitated (Farmer et al., 2012). In Scotland, the 2015 Community Empowerment Act devolves certain powers to communities, while the ten year Social Enterprise Strategy co-produced with the sector and published in 2016 promotes social enterprise as a potential means of complementing and enhancing state provision of services (Scottish Government, 2015; Scottish Government, 2016). A history of policy which views communities as resources for 'bottom-up' regeneration activities has been noted in Europe and North America (Amin et al., 1999) and some commentators suggest that policy has sought to achieve community development through ubiquitous social enterprise (Farmer et al., 2012). In the U.K. and Australia, governments have been criticised for promoting social enterprise as a means for third sector organisations to deliver more social goods (Roy and Hackett, 2017). Indeed, policy which focuses on community empowerment has been linked to the retreat of the state from the provision of services (Moore and McKee, 2014) and criticised as a means to protect state resources (Amin et al., 2003). Thus, 
social enterprise that is 'prescribed' by the state has been problematised within the context of declining state resources.

Social enterprises are attractive as a development tool because they are assumed to be self-financing through their trading activities and an ideal mechanism for empowering excluded groups and democratising regeneration activities (Amin et al., 1999). In the UK policy environment, social enterprises are understood to be businesses which trade for income and invest their surpluses in the business or the community to pursue social objectives (Department of Trade and Industry, 2002). Community social enterprises are particularly attractive due to assumptions that they will build on latent activity within communities, such as local practices of mutual assistance and informal support (Gibson and The Community Economies Collective 2013). In so doing, individuals - and the relationships between them - are re-envisioned as 'social assets' that can be used for development purposes, a view which resonates with understandings of the third sector as founded on values of caring for others and meeting social needs (Amin, 2009; Pearce, 1993). As such, community social enterprises are portrayed as self-sufficient organisations that mobilise social capital and engage with the market.

The idea that market-based models of social enterprise can simply build on existing layers of community practices is problematic. Evidence suggests that business models might not be compatible with the values underpinning the third sector, and there is sufficient theoretical basis and empirical evidence to suggest that the third sector offers a different way of experiencing economic life to the private and public sectors. Third sector organisations are places of trust and solidarity where principles of care and mutual assistance are embedded (Borzaga and Galera, 2012; Pearce 1993) and there is an argument that third sector organisations have value in and of themselves in facilitating wellbeing (Farmer et al. 2016; Macaulay et al., 2017). Critics have maintained that the incorporation of private market values threatens the ability of third sectors organisations to create and maintain social capital, thus posing a risk to civil society and democracy (Eikenberry and Kluver, 2004).

That community social enterprise is an empowering form of development intervention is also open to debate. Farmer et al. (2012) note that the skills and abilities often required for social enterprise may be 
unequally distributed, and that attempts to harness them might reinforce geographies of disadvantage. Atkinson (1999) highlights that communities and individuals are often disadvantaged not only in their access to resources but also in the terms in which they think about what is possible. It is often those who control the discourse of empowerment at a policy level who determine the scope of what constitutes 'appropriate' activities, therefore reinforcing existing social relations (1999). Likewise, Stanton (2014) contends that while some policies are designed to counter centralism and encourage community selfdetermination, this self-determination is often practiced under the supervision of and within boundaries set by local and central government. Indeed, Bailey and Pill (2011) identify a paradox between the rhetoric of community empowerment and a shift towards centralisation of power in developed economies. Thus, community social enterprise that is prescribed by government and facilitated by professionals has the potential to reinforce or exacerbate unequal power relations.

Community social enterprise as an empowering intervention is further complicated by the practicality of implementation. Farmer et al. (2012) suggest that there is obscurity around how the ideology of ubiquitous social enterprise will be translated into action, and how communities will translate their latent activity into social enterprise activity. If this approach envisions individuals as assets and mobilises them for development, then it requires as a pre-requisite a skilled base of individuals. It is not currently known whether communities have the skills and abilities to implement these policy directions and this necessarily has implications for whether or not moves towards the empowerment of communities via social enterprise development are achievable.

\section{Methodology}

The study takes an 'instrumental' (Stake, 1995) form of case study which focusses on a project to develop a consortium of social enterprise community gardens in a peri-urban area of central Scotland (“the Project”). Funding was awarded by a Scottish Government-administered European Funding programme in April 2017 and the project began in May 2017 for a period of six months. During this time, Project Managers from two organisations funded to deliver the project recruited representatives of community gardens to attend facilitated meetings in which they would work towards a number of 
outcomes, including those stipulated by the funder in the Project brief. The Project responded to findings that the community growing sector in Scotland is struggling with funding and resource shortages (FCFCG, 2016) and was premised on the idea that community growing initiatives can be more sustainable when they work together. Thus, the focus of the Project was the sustainability and growth of community growing initiatives, particularly in more vulnerable communities where resources are required to build capacity. The Project aimed at developing a new community social enterprise in the form of a consortium. This would improve the sustainability of individual community gardens and enable them to deliver more local services through collaboration and developing income streams. In addition, the funder stipulated that the Project must map the skills and expertise of the sector and pilot a new community growing evaluation tool.

The formation of consortia by social enterprises is not a new concept. Social enterprises in the UK have formed federations (Altrum, 2017), and in Italy co-operatives have traditionally formed local consortia which function as 'strategic support in the contractual relations between co-operatives and public authorities, often acting as general contractors' (Borzaga and Santuari, 2004: 176). Social enterprise consortia in Scotland can be understood within the context of public policy support for scaling up the delivery of public services by social enterprises. Scottish Government has endorsed consortia bidding for public sector contracts and funded research to identify barriers to social enterprise consortia formation (Holmes et al., 2009). In addition, the Scottish Government sponsored Ready for Business scheme offers capacity building support to establish consortia of third sector organisations to bid for public sector contracts.

We set out to investigate the roles of the various actors involved in the project. Meetings and site visits were undertaken prior to formal interviews to build rapport with participants, become familiar with the research setting and try and understand the context - including the local political context - of what was being planned. Project Managers and community representatives were identified and 'purposively' (Mason, 2002) sampled for conducting in-depth semi-structured interviews. The interviews were augmented by participant observation written up into field notes, which also included participation by the lead researcher in meetings. Data were also gathered from documents relating to the various 
organisations (or nascent organisations) involved in the project, including their websites where these were available.

Interviews were conducted with two Project Managers (PM1 and PM2) and four community representatives (RepA, RepB, RepC and RepD) between June and July 2017. All research participants were female. Both Project Managers were paid development workers with a remit to develop social enterprise in the region. Three community representatives were also paid development workers, and one was a volunteer (RepD). It transpired that Rep D was the only representative of a social enterprise with an active community garden: RepA and RepB represented organisations that did not have a community garden yet, and RepC's community garden was on hold. The characteristics of the participants in the study and the organisations they represented are outlined in tables 1 and 2.

Table 1: The participants in the study

\begin{tabular}{|l|l|l|l|l|}
\hline & Role & Type of Organisation & $\begin{array}{l}\text { Time in } \\
\text { Post }\end{array}$ & $\begin{array}{l}\text { Currently } \\
\text { Growing? }\end{array}$ \\
\hline Rep A & $\begin{array}{l}\text { Community } \\
\text { Development } \\
\text { Worker }\end{array}$ & Development Trust & 2 months & No \\
\hline Rep B & $\begin{array}{l}\text { Community } \\
\text { Development } \\
\text { Worker }\end{array}$ & Development Trust & 2 years & No \\
\hline Rep D & $\begin{array}{l}\text { Community } \\
\text { Development } \\
\text { Worker }\end{array}$ & Community Association & $10+$ years & On hold \\
\hline $\begin{array}{l}\text { Project } \\
\text { Manager 1 }\end{array}$ & $\begin{array}{l}\text { Solunteer } \\
\text { Development } \\
\text { Worker }\end{array}$ & $\begin{array}{l}\text { Community Growing } \\
\text { Dembership } \\
\text { Organisation }\end{array}$ & 1 year & n/a years \\
\hline $\begin{array}{l}\text { Project } \\
\text { Manager 2 }\end{array}$ & $\begin{array}{l}\text { Social Enterprise } \\
\text { Development } \\
\text { Worker }\end{array}$ & $\begin{array}{l}\text { Local Council for } \\
\text { Voluntary Services }\end{array}$ & 2 years & n/a \\
\hline
\end{tabular}


Table 2: The organisations represented in the study

\begin{tabular}{|c|c|c|c|c|}
\hline & $\begin{array}{l}\text { Type of } \\
\text { Organisation }\end{array}$ & Legal Structure & Ownership & Social Purpose \\
\hline $\operatorname{Rep} A$ & $\begin{array}{l}\text { Development } \\
\text { Trust }\end{array}$ & $\begin{array}{l}\text { Registered } \\
\text { Charity }\end{array}$ & $\begin{array}{l}\text { Voluntary } \\
\text { Community } \\
\text { Organisation }\end{array}$ & $\begin{array}{l}\text { To support economic } \\
\text { and social regeneration }\end{array}$ \\
\hline $\operatorname{Rep~B}$ & $\begin{array}{l}\text { Development } \\
\text { Trust }\end{array}$ & $\begin{array}{l}\text { Charitable } \\
\text { Company } \\
\text { Limited by } \\
\text { Guarantee }\end{array}$ & $\begin{array}{l}\text { Voluntary } \\
\text { Community } \\
\text { Organisation }\end{array}$ & $\begin{array}{l}\text { To achieve the } \\
\text { sustainable regeneration } \\
\text { of the community } \\
\text { through addressing the } \\
\text { Economic, Social, } \\
\text { Environmental and } \\
\text { Cultural needs }\end{array}$ \\
\hline $\operatorname{Rep} C$ & $\begin{array}{l}\text { Community } \\
\text { Association }\end{array}$ & $\begin{array}{l}\text { Charitable } \\
\text { Company } \\
\text { Limited by } \\
\text { Guarantee }\end{array}$ & $\begin{array}{l}\text { Voluntary } \\
\text { Community } \\
\text { Organisation }\end{array}$ & $\begin{array}{l}\text { Community food } \\
\text { project and learning } \\
\text { centre }\end{array}$ \\
\hline $\operatorname{Rep} D$ & $\begin{array}{l}\text { Development } \\
\text { Trust }\end{array}$ & $\begin{array}{l}\text { Charitable } \\
\text { Company } \\
\text { Limited by } \\
\text { Guarantee }\end{array}$ & $\begin{array}{l}\text { Voluntary } \\
\text { Community } \\
\text { Organisation }\end{array}$ & $\begin{array}{l}\text { Community Food } \\
\text { Project }\end{array}$ \\
\hline
\end{tabular}

An audio-recording was made of all interviews with the permission of all participants and all were transcribed verbatim. Structural coding (Saldaña, 2016) of these data was then undertaken, which allowed commonalities, differences and relationships within the data to be identified. Findings were then examined through the lens of Muñoz and Steinerowski's (2012) 'theory of social entrepreneurial behaviour'. Muñoz and Steinerowski (2012) built on previous theories of the skills of individuals in social enterprise (Dees, 1998; Nicholls, 2008; Zahra et al., 2009) to broadly categorise the skills required for community social enterprise into three capability domains: 'opportunism', by identifying social needs, establishing a social mission and identifying a solution to that need; 'leadership', by catalysing others in pursuit of a social mission, generating new ideas and mobilising resources by bringing in staff and volunteers; and 'networking', by building relationships to bring resources to the enterprise and building discursive legitimacy at local, regional and national levels (2012) (as explained in Table 3). Themes and patterns in the data were identified using theoretical thematic analysis (Braun and Clarke, 2006), which sought to identify similarities between participant accounts and Muñoz and Steinerowsksi's (2012) theoretical framework. This approach allowed us to ascertain which actors in 
this Project had demonstrated the relevant skills to undertake the different roles required for establishing a new community social enterprise in the form of a consortium.

Table 3: Theory of Social Entrepreneurial Behaviour (adapted from Muñoz and Steinerowski, 2012)

\begin{tabular}{|c|c|c|}
\hline $\begin{array}{l}\text { Entrepreneurial } \\
\text { capability domain }\end{array}$ & Social entrepreneurial skills & $\begin{array}{l}\text { Associated social } \\
\text { entrepreneurial processes }\end{array}$ \\
\hline \multirow[t]{2}{*}{ Opportunism } & Opportunity perception & $\begin{array}{l}\text { Identification of social needs } \\
\text { and establishment of a social } \\
\text { mission }\end{array}$ \\
\hline & $\begin{array}{l}\text { Generation of new ideas } \\
\text { Ability to overcome problems and } \\
\text { challenges }\end{array}$ & $\begin{array}{l}\text { Identification of ways to meet } \\
\text { social needs through } \\
\text { enterprising solutions }\end{array}$ \\
\hline \multirow[t]{3}{*}{ Leadership } & $\begin{array}{l}\text { Vision for combining social and } \\
\text { economic goals within an organisational } \\
\text { model }\end{array}$ & $\begin{array}{l}\text { Effective combining of social } \\
\text { and economic goals }\end{array}$ \\
\hline & Ability to mobilise resources & Bring in staff and volunteers \\
\hline & Catalyse action of others & $\begin{array}{l}\text { Catalyse others to act in aid of } \\
\text { the social mission }\end{array}$ \\
\hline \multirow[t]{4}{*}{ Networking } & Building of discursive legitimacy & $\begin{array}{l}\text { Building of discursive } \\
\text { legitimacy through support for } \\
\text { the social mission }\end{array}$ \\
\hline & Drawing in of resources & $\begin{array}{l}\text { Builds relationships that bring } \\
\text { resources to the enterprise }\end{array}$ \\
\hline & Knowledge arbitration & \\
\hline & Utilising and strengthening social capital & \\
\hline
\end{tabular}

\section{Findings}

The interviews with community representatives and Project Managers revealed confusion about the purpose of the Project and highlighted several issues relating to the roles of individuals within the 
project. These issues are grouped in the following themes: the dominance of Project Managers in social entrepreneurial roles within the Project; inconsistency between the external and community-based actors about the purpose of the Project; and different ideas about the solution to be provided by the Project. Each of these themes is discussed in turn.

\section{Dominance of Project Managers}

Social entrepreneurial skills and processes were present within this Project, but these were dominated by Project Managers. Skills and processes within the three capability domains of opportunism, leadership and networking were identified.

Within the capability domain of opportunism, the identification of social needs and the establishment of a social mission are believed to be the first stage in the development of community social enterprises (Haugh, 2005; Muñoz and Steinerowski, 2012). In this project, Project Managers had undertaken this process. Talking about how the project originated, PM1 stated:

it was responding to the needs of the community, but it wasn't specifically asking them. So, it concerned me at first (PM1).

The process of needs identification did not seem to involve the input of community members. Statements from community representatives confirmed that they were not aware of the Project until Project Managers invited them to attend the first meeting. By this time, funding was secured and the outcomes of the Project had been stipulated by the funder. The Project Manager seemed to be indicating the problematic nature of the community not having been asked what their needs were in advance of the project, and thus acknowledged that the community perception of need may well not align with her own perceptions.

The following exchange was also observed:

RepA: it would be good to know as well whether there is - how much prescription there's gonna be. 
Researcher: prescription from who?

RepA : oh just from the people running the group.

The community representative did not perceive herself to be in a position of leadership within the Project; she was looking to the Project Managers to prescribe activities. This statement also suggests confusion on the part of RepA about the format of the Project and how it would be delivered.

Within the capability domain of networking, Muñoz and Steinerowski (2012) found that social entrepreneurial actors must build 'discursive legitimacy' for their enterprise through building support for the social mission at local, regional and national levels, and build relationships to bring resources to the enterprise. Project Managers in this project dominated the process of building discursive legitimacy and bringing resources to the project through networking. In the following account, PM1 recalls her first visit to the region when she attended a public meeting and met representatives of the local council:

it really got me thinking this was the community to work in, 'coz the council seemed on board. And sure enough we've got a meeting with the head of Planning in a couple weeks... [PM2] used to work for the council so she got our foot in the door. So, I think there's a lot of goodwill here (PM1).

This seemed to suggest that Project Managers used their own contacts to build discursive legitimacy at the political level. There was a sense that the location of the Project was chosen to align with the priorities of the local authority, rather than the needs of the local communities per se. However, there was no mechanism within the Project for building discursive legitimacy at the community level. Only one person per community was represented in Project meetings, and community members had not told their colleagues about the Project:

Within reason I've told them about it but we didn't really.... there was nothing kind of concrete yet (RepB). 
The meetings we had - which are so existential here, like about what's happening here because of the redundancies and everything - so this [the Project] is a bit like, it's sort of, you know, it [the Project] goes on in the background (RepC).

These statements suggest that community representatives were reluctant to share information with colleagues about the Project because they were unclear about its purpose, and that the project was not as important as challenges in the day-to-day running of their organisations. As such, community representatives were, in effect, acting as 'proxies' for colleagues and members of the wider community in this Project. Indeed, the Project Managers were also acting as proxies for community members when designing the project and applying for funding.

\section{Diverging Views of Needs}

The lack of community involvement in the Project design was also reflected in diverging perceptions of the purpose of the Project between actors from within and outside of the community. While both types of actor sought to develop the capacity of the community growing sector, community representatives were motivated to participate in the Project to access skills and learn from each other. By contrast, Project Managers sought to bring financial resources into the sector through business development.

There was a clear suggestion from interviews that community representatives wanted to set up or run a community garden to add value to their communities, as demonstrated by the following statements:

I would really like to see improved health outcomes from vegetable consumption, but also I know that there are other improved health outcomes from working outdoors, from engaging with other members of the community, from (the) physical activity of gardening (RepA).

Colleges struggle to place some students in the community on placements. Because they either have behaviour difficulties, or learning difficulties. So, we literally did not knock anyone back, ever... and to be honest, we done a really successful job out of it. We had such good feedback, from so many placements (RepC). 
By talking about their community gardens as places that can facilitate improvements in health, wellbeing and the inclusion of excluded groups, community representatives identified certain unmet needs in their communities and saw the community garden as a potential solution to these unmet needs. Viewed through the lens of social entrepreneurial behaviour this behaviour can be seen as evidence that the community representatives demonstrated skills in opportunity perception and generating new ideas.

However, some respondents felt that they did not have the necessary capabilities to deliver a community garden successfully and believed that the Project would help them access knowledge, expertise and advice. Community representatives discussed the Project as a way to create a new network of relationships between gardens and facilitate the exchange of information and support:

Because I've not got any direction with the garden, I need to know what I'm doing before I can ask other people to come in and start doing stuff (RepB).

It's sharing, really. Sharing ideas, sharing information, and helping each other out (RepC).

So you've got the support of these other organisations, so that they can help guide, you know, don't plant peas now... if you do this then that'll work. So that's, that was what I was hoping to gain, initially (RepB).

It would be good to have some support with 'this tends to work for community gardens'... you know, you need to engage this many volunteers... you need at least five people every week... there must be some key things that go into making a garden a success I imagine (RepA).

In these statements, community representatives describe the Project as an opportunity to learn from each other and gain very practical advice about gardening. There is also a sense that participating in the Project was a way to build connections and help respondents to overcome challenges and bring resources into their own community organisations. Within the framework of social entrepreneurial behaviour, community representatives can be understood as social entrepreneurial actors who used networking skills to strengthen social capital and arbitrate knowledge. 
Not all community representatives were interested in learning from others. RepD was the only representative of an operational garden and was least clear on her motivations for participating in the Project:

I don't know that I really thought of it as something to benefit us, actually. I hadn't thought of it as that. Um, I dunno why, but I just thought that they... needed participating gardens! And it would be good to be one of the participants. I wanted to make it as good for them as possible (RepD).

RepD indicated in this statement that she had attended a Project meeting because she had been asked and wanted the organisers to have a good turnout. RepD seemed least motivated to acquire new social entrepreneurial skills and did not seem to think that her community garden had much to gain from the Project.

Project Managers had different ideas from community representatives about how to develop the capacity of the sector. PM1 gave the following account when talking about the motivations for the project:

the demoralisation of all the funding cuts and all the chipping away and the less hours and less money, has had an effect on the groups. So, we really need to do something with them (PM1).

Project Managers drew attention to the financial problems facing the sector and positioned these as the main stimulus for the Project. PM2 described how forming a consortium would help community gardens overcome these issues:

hopefully some income being generated from it, and that might be through directly selling produce and getting that to market but it also might be through getting little commissions or codesigning services with the council, or with the health service (PM2).

It's about how do you share resources better across the sector so, rather than having 7 little community gardens each chasing their own separate pots of funding and each struggling away with the same issues, how do we share a bit more. If somebody gets some money for new 
equipment, can that equipment be used. You know if we're trying to train up a bunch of volunteers for community gardening can we have some way that those volunteers can go to different gardens, and not just one (PM2).

In these discussions of the purpose of the consortium, PM2 identified income generation, through sales and contracting, as a way to help community gardens overcome resource shortages. PM2 believed that the Project would work towards this goal by developing a consortium of community growing initiatives that could apply for funding and commissions collectively as well as share resources such as equipment and volunteers.

PM1 also talked about the Project as a way to plan for generating income collaboratively:

this actually came from [my colleagues] down south... we were talking about how we wanted to stop tryna work with individual groups. Some of the groups individually, yes, have enough income generation potential to work with. But many of the other ones should be linked up, we thought (PM1).

the mindset I'm looking at helping support is more collaborative working that allows for that mix of people. Rather than having some groups one way, this other group another way... people can maybe share some vision and share some activity... $2+2$ could equal 6 . And also for enterprise activities as well. To be able to work together on bags, veg schemes, or bag schemes, or growing in sync. You grow the cabbages, I'll grow the whatever, and we can all take the stuff to the food bank in the summer. You know, the spirit of working together sort of thing (PM1).

PM1 and her colleagues had acknowledged that many community gardens were too small to generate income and saw this Project as a way to enhance their income generation potential by bringing them together. Collaboration in the Project was also seen as a way to change community representatives' mind-set's about working with others and develop a shared vision for working together. PM1 expressed a desire for a spirit of collaboration to be mobilised to develop income generating vegetable bag 
schemes (a scheme for community food co-ops to sell fresh produce) or donate produce to the food bank.

Thus, while both external and community-based actors saw the Project as a means to facilitate collaboration, views on the purpose and nature of the collaboration differed. One explanation for this may be that the community gardens involved in this Project were not at the stage of development that would enable them to achieve business development. Activities like trading and contracting require community gardens to be established and fully operational, but only one of our respondents - Rep D represented an active garden. Importantly, Rep D did not seem overly motivated to participate in the project and could not see how it would benefit her. The case of RepD provides further evidence of a fundamental misalignment between the project brief and community representative priorities and hints that while the Project was a useful arena for those who sought to build capacity, it was less useful for the community representative whose garden was running successfully.

\section{Unsuitable Solution}

There was an overall sense that the aims of the Project were not in line with the day-to-day issues experienced by respondents in trying to establish and run a successful community garden. This was made clear by respondents when they talked about the activities that had been stipulated in the project brief by the funder:

You can have all these capacity, and network, and everything. But if the Projects can't, are struggling with running - yeah you have volunteers but volunteers just like to come and get involved - you know it needs this middle bit. Who will manage this? Who will support it? (RepC).

When we are looking at these outputs, you know mapping and expertise, that's fine you can have a map of it and then chuck it on a shelf or in a cupboard. But actually showing how - to make these outputs live outputs - things that once this has finished, and you go home, we still look at this and we are still using it as a group, and it's still an active thing that's actually happening. Rather than something we did (RepB). 
These statements reinforce the idea that community representatives sought to acquire knowledge and skills and looked to Project Managers for leadership in this Project. They also draw attention to the fact that community gardens in the region were struggling and required support to keep them operational. However, they also indicate that the aim of the project - to develop a consortium - was not necessarily the type of support that they required. We can see that community representatives were concerned to translate the activity of the Project to tangible outcomes of practical value to their local communities. However, each community representative sought to address different issues and chose to discuss elements of the Project brief that were relevant to them, while ignoring others. In fact, community representatives even directly asked the lead researcher to clarify aspects of the Project and there was considerable evidence of confusion among respondents about the way that the project would meet their needs.

The tension between Project Manager and community representative views can clearly be seen in by comparing views on funding the sector. From the perspective of the Project Managers, the purpose of the project was to encourage collaboration and draw more financial resources to the sector, through trading for income and bidding for contracts which would increase financial sustainability. However, while respondents agreed with the principle of generating income from trading, they seemed to remain unconvinced that a great deal of money was actually required to do what they wanted to do:

We're looking into it, how we can be more self-sustainable, because what the guys, our volunteers, and the girls, like doing is making stuff from produce. We always like, we've got a good herb bit, so dry the herbs and sell the herbs, make things and sell things rather than just sell produce, which we do. But make chutneys and sell them, make herbs and... recycle bottles and sell them. So yeah. And we've got worms, so we can sell, like, worm casts, run courses on, like, wormeries and stuff so... Ok so it's not a lot, we won't make a lot of money, but you don't need a lot of money. Before, after the regional funding ran out, and before the CCF kicked in, we really survived on nothing. And we were so proud of it. We were like 'we do a lot with very little!'. You know. Everything's recycled, everything's kind of reused. It was, it was good. So, it's actually better (RepC). 
We sell honey as well, from the bees. And yeah, those kind of things, they're all good for making a few bob. But we've - I mean the garden is incredibly cheap! The only thing that costs money is when you have to pay lawyers or - salaries, actually! ... But if you do it yourself, and you use what expertise you have - and also I think that seeds cost practically nothing. Seed potatoes - we sold seed potatoes and with the money from that we buy our next lot. You know, that covers it (RepD).

These accounts suggest the reluctance of the community representatives to become 'entrepreneurial' in the way that was being presented to them. RepC indicated that trading activity would generate only small amounts of money, while RepD alluded that behaving like a business (by employing staff or lawyers) was more costly than cost-effective. The community representatives believed that community gardens can be self-sufficient in other ways through recycling and volunteering, and that this form of self-sufficiency is preferable to a reliance on market-based activity. Indeed, these statements give an indication of a distinct set of values in the community growing sector based around thrift and selfreliance.

Respondents provided further evidence the values of the growing sector may not be compatible with the values associated with over-reliance upon market-based activity:

And you attract more genuine people when you're not just about money. When you're not constantly chasing funding. It's really not nice. I've learned a lot in this... Don't be top heavy. We became hugely top heavy. Like huge overheads, huge costs, management... rubbish. Why do the gardens need that? It's crazy (RepC).

We've talked about paid staff, we've thought wouldn't that be nice... but also thought there's the downside of that, is that sometimes you lose the impetus of the volunteers, if they see somebody's getting paid for what they're doing...they've got to enjoy it. It's got to be an enjoyable thing. They're not doing it because they ought to, or they should. They've really got to. And if they don't, if they're not enjoying it any longer, I would say it's best if they... did something else (RepD). 
Community representatives perceived the support and engagement of local people to be crucial to the success of growing initiatives and there was a strong commitment to values such as voluntarism, community action and mutual assistance that are not necessarily compatible with the market. Community representatives were more concerned with networking, sharing and helping each other, contrasting markedly with the Project Managers ambitions for the project.

\section{Discussion and Conclusions}

Our intention in this paper was to explore whether facilitated social enterprise benefits or disempowers communities. In order to do this, we explored the roles of actors both within and outside the communities involved, drawing on an instrumental case study of a project focused on stimulating social enterprise in community garden projects. The findings that emerge from this are now discussed.

\section{Social Entrepreneurial Skills and Capabilities}

Reflecting upon the social entrepreneurial skillsets and capabilities outlined by Muñoz and Steinerowski (2012) our study found that community members had a low level of participation to processes that would be recognisable as being 'socially entrepreneurial' and that in most instances, it was project managers who possessed many of the 'enterprise' skills. The study also found that community members perceived themselves to lack many of the skills required to deliver social enterprise in their communities. While not problematic in and of itself - as long as the community were comfortable that they could draw upon skills or expertise from outside (Roy et al., 2015) - where there is a disjuncture between the vision of actors within and outside the community, this can manifest in activities that run the risk disempowering communities. Imposing a market-based social enterprise way of working upon people who enjoy and value maintaining localised projects founded upon ethics of voluntarism and sharing is potentially destructive.

However, we also find that individual and collective action to community development projects whether via a social enterprise model or not - are not mutually exclusive. While community representatives and Project Managers did not agree on the purpose of the Project, there was, in fact, evidence to suggest that the Project was of value to some community representatives by bringing them 
into contact with others and facilitating learning. Even though this was not what the Project set out to do, collaboration was the means by which individual community members sought to enhance their skills and it is worth acknowledging the potential for skills development initiatives to be done in a collective way. Improving the collective efficacy of communities is a valuable outcome in and of itself (Teig et al., 2009).

It is also important to note that the financial needs of the growing sector outlined by Project Managers do reflect real issues. Funding cuts to the sector were acknowledged by community representatives when talking about redundancies and respondents felt that a reliance on funding and grants undermined the sustainability of community gardens. Funding is inconsistent, and renewed funding is difficult to secure due the onerous nature of applications and impact measurement and cuts to the amount of funding available. If funding is not renewed, projects are unable to continue to employ staff which leaves no one to run projects. This affects the continuity of projects and the services they offer in their communities. However, respondents did not seem to see market-based social enterprise as a means to solve their financial issues. Community representatives did not display a willingness to operate at the scale proposed by the project managers i.e. as a consortium. Instead, community representatives showed a desire to move away from funded organisational models, which they perceived as unreliable and incompatible with community growing.

\section{The Empowerment of Communities through Social Enterprise}

We have seen in previous studies that certain roles within the process of community social enterprise creation (such as needs identification and initiation of action) require to be community-led (Haugh, 2007; Muñoz et al., 2014) in order to be 'successful', or at least not to disempower the communities in question. Unfortunately, despite decades of understanding how good community development can be undertaken, we are still seeing evidence of external actors imposing a model of working that is insufficiently aligned with the needs and aspirations of community members. In this study, policy-level discourses which present market-based social enterprise as an empowering development tool were able 
to dominate community social enterprise development and supported powerful actors to act as proxies for communities and access resources on their behalf.

Two implications arise from this: Firstly, policy which aims to empower excluded groups and democratise regeneration through externally stimulating and facilitating social enterprise may in practice most support actors that possess the skills and resources to build discursive legitimacy at the political level. It is well known in literature that these capabilities may not be equitably distributed and often relies on key individuals (see for example Muñoz et al., 2014; Radford and Shortall, 2012; Roy et al., 2015). It is also well known that the scope of local economic development activity is still largely dictated by policy and funding priorities (Atkinson, 1999; Stanton, 2014). Current policy may therefore do more to reinforce geographies of disadvantage than facilitate social inclusion (Farmer et al. 2012) as well as reinforce existing power relations. As such, ideas of community empowerment may indeed be more rhetoric than reality (Bailey and Pill, 2015).

A related issue concerns the methods employed by professionals who seek to facilitate social enterprise activity. Our research raises ethical issues concerning externally stimulated social enterprise. In this study, community members perceived themselves as unskilled and Project Managers as powerful actors with the ability to negotiate policy discourses and access resources. Unequal power relationships, if allowed to go unchecked, can disempower communities. Introducing social enterprise from outside however well-meaning the initial intentions - needs to be undertaken very carefully indeed.

The potential for disempowerment therefore raises implications for decision makers about how funding programmes are experienced by social enterprise practitioners. The views of community members should be better incorporated into the funding application process and assumptions cannot be made that actors from outside can adequately represent the needs and aspirations of a community.

\section{Unrealistic Expectations}

A second implication of our findings is the disconnection between policy expectations for social enterprise and misconceptions about the need for social enterprises. Policy in Scotland has encouraged the development of social enterprise on the premise that it is self-financing through trading activity and 
can contribute to the empowerment of communities (Scottish Government, 2016). This study confirms suspicions that this assumption may not adequately reflect reality (Dey and Steyaert, 2012; Mazzei and Roy, 2017) and could potentially undermine values of mutual assistance, caring for others and meeting social needs are inherent to the third sector (Amin, 2009; Borzaga and Galera, 2012; Pearce, 2003). The findings suggest too that the capacity needs of the community growing sector are not necessarily aligned with government priorities and there may be an inherent - possibly irreconcilable - tension between financial and social priorities (Cornforth, 2014; Garrow and Hasenfeld, 2014; Teasdale, 2012). Policies which encourage community organisations to become sustainable through market-based activity may end up working at odds with the values held by practitioners in the sector. This study instead suggests that developing relationships and facilitating skills exchange at the community level is crucial. One key lesson, then for policy and practice, is that imposing or insisting upon the 'social enterprization' of community projects without the critical backing of the communities in question is unlikely to succeed and, in fact, is far more likely to disempower and disenfranchise people instead.

This paper aimed to understand whether facilitated social enterprise benefits or disempowers communities and challenges current thinking about social enterprise as an empowering development tool. We have shown that community development occurs within the boundaries set by a policy discourse of market-based models of social enterprise, and that this type of social enterprise may not align with the needs and aspirations of local communities. Further, the skills required to deliver this type of social enterprise are not necessarily readily available and the leadership of professionals is predominant at community level. This paper therefore provides preliminary information about possible barriers to empowerment using the facilitated social enterprise approach and raises the question of whether empowerment via market-based community social enterprise is realistic or indeed desirable. 


\section{References}

Al-Dajani, H., Marlow, S., 2013. Empowerment and Entrepreneurship: A Theoretical Framework. Int. J. Entrep. Behav. Res. 19, 503-524. https://doi.org/10.1108/IJEBR-10-2011-0138

Amin, A., 2009. Extraordinarily Ordinary: Working in the Social Economy. Soc. Enterp. J. 5, 30-49. https://doi.org/10.1108/17508610910956390

Amin, A., Cameron, A., Hudson, R., 2003. The Alterity of the Social Economy. Altern. Econ. Spaces 27-54.

Amin, A., Cameron, A., Hudson, R., 1999. Welfare as Work? The Potential of the UK Social Economy. Environ. Plan. A 31, 2033-2051.

Atkinson, R., 1999. Discourses of Partnership and Empowerment in Contemporary British Urban Regeneration. Urban Stud. 36, 59-72.

Bailey, N., Pill, M., 2011. The Continuing Popularity of the Neighbourhood and Neighbourhood Governance in the Transition from the 'Big State' to the 'Big Society' Paradigm. Environ. Plan. C Gov. Policy 29, 927-942. https://doi.org/10.1068/c1133r

Braun, V., Clarke, V., 2006. Using thematic analysis in psychology. Qualitative Research in Psychology. 3, 77-101.

Borzaga, C., Galera, G., 2012. The Concept and Practice of Social Enterprise. Lessons from the Italian Experience. Int. Rev. Soc. Res. 2. https://doi.org/10.1515/irsr-2012-0019

Borzaga, C., Santuari, A., 2004. Italy, in: Evers, A., Laville, J.-L. (Eds.), The Third Sector in Europe. Edward Elgar, Cheltenham, UK, pp. 166-181.

Chell, E., 2013. Review of Skill and the Entrepreneurial Process. Int. J. Entrep. Behav. Res. 19, 6-31. https://doi.org/10.1108/13552551311299233

Corner, P.D., Ho, M., 2010. How Opportunities Develop in Social Entrepreneurship. Entrep. Theory Pract. 34, 635-659. https://doi.org/10.1111/j.1540-6520.2010.00382.x

Cornforth, C., 2014. Understanding and Combating Mission Drift in Social Enterprises. Soc. Enterp. J. 10, 3-20. https://doi.org/10.1108/SEJ-09-2013-0036

Dart, R., 2004. The Legitimacy of Social Enterprise. Nonprofit Manag. Leadersh. 14, 411-424.

Dees, J.G., 1998. The Meaning of "Social Entrepreneurship."

Defourny, J., Nyssens, M., 2008. Social Enterprise in Europe: Recent Trends and Developments. Soc. Enterp. J. 4, 202-228. https://doi.org/10.1108/17508610810922703

Department of Trade and Industry, 2002. Social Enterprise: A Strategy for Success.

Dey, P., Steyaert, C., 2012. Social Entrepreneurship: Critique and the Radical Enactment of the Social. Soc. Enterp. J. 8, 90-107. https://doi.org/10.1108/17508611211252828

Di Domenico, M., Haugh, H., Tracey, P., 2010. Social Bricolage: Theorizing Social Value Creation in Social Enterprises. Entrep. Theory Pract. 34, 681-703. https://doi.org/10.1111/j.15406520.2010.00370.x

Drayton, W., 2011. Everyone a changemaker: Social entrepreneurship's ultimate goal, in: Petit, P.U. (Ed.), Creating a New Civilization Through Social Entrepreneurship. First Transaction Publishers/Goi Peace Foundation, Piscataway, NJ, pp. 53-62.

Eikenberry, A.M., Kluver, J.D., 2004. The Marketization of the Nonprofit Sector: Civil Society at Risk? Public Adm. Rev. 64, 132-140.

Farmer, J., Hill, C., Muñoz, S.-A., 2012. Community Co-Production: Social Enterprise in Remote and Rural Communities. Edward Elgar, Cheltenham, UK.

FCFCG., 2016. FCFCG Scotland Members Annual Survey 2016. 
Fletcher, D.E., 2006. Entrepreneurial Processes and the Social Construction of Opportunity. Entrep. Reg. Dev. 18, 421-440. https://doi.org/10.1080/08985620600861105

Garrow, E.E., Hasenfeld, Y., 2014. Social Enterprises as an Embodiment of a Neoliberal Welfare Logic. Am. Behav. Sci. 58, 1475-1493.

Gibson, K., The Community Economies Collective, 2013. Building Community-Based Social Enterprises in the Philippines: Diverse Development Pathways, in: Amin, A. (Ed.), The Social Economy: International Perspectives on Economic Solidarity. Zed Press, London.

Haugh, H., 2007. Community-Led Social Venture Creation. Entrep. Theory Pract. 31, 161-182.

Holmes, J., Holmes, A., Sear, L., Regan, A., Smith, C., Butler, B., 2009. Opportunities and Barriers to Consortia Bidding for Public Sector Contracts.

Jackson, B., Nicoll, M., Roy, M.J., 2018. The Distinctive Challenges and Opportunities for Creating Leadership Within Social Enterprises. Soc. Enterp. J. 14, 71-91. https://doi.org/10.1108/SEJ03-2017-0016

Leadbeater, C., 1997. The Rise of the Social Entrepreneur. Demos, London.

Macaulay, B., Roy, M.J., Donaldson, C., Teasdale, S., Kay, A., 2017. Conceptualizing the Health and Well-Being Impacts of Social Enterprise: A UK-Based Study. Health Promot. Int. https://doi.org/10.1093/heapro/dax009

Martin, R.L., Osberg, S., 2007. Social Entrepreneurship: The Case for Definition. Stanf. Soc. Innov. Rev. 11, 1-17.

Mason, J., 2002. Qualitative Researching. SAGE, London.

Mazzei, M., Roy, M.J., 2017. From Policy to Practice: Exploring Practitioners' Perspectives on Social Enterprise Policy Claims. Volunt. Int. J. Volunt. Nonprofit Organ. 28, 2449-2468. https://doi.org/10.1007/s11266-017-9856-y

Montgomery, A.W., Dacin, P.A., Dacin, M.T., 2012. Collective Social Entrepreneurship: Collaboratively Shaping Social Good. J. Bus. Ethics 111, 375-388. https://doi.org/10.1007/s10551-012-1501-5

Moore, T., McKee, K., 2014. The Ownership of Assets by Place-Based Community Organisations: Political Rationales, Geographies of Social Impact and Future Research Agendas. Soc. Policy Soc. 13, 521-533. https://doi.org/10.1017/S1474746413000481

Muñoz, S.-A., Steiner, A., Farmer, J., 2014. Processes of Community-Led Social Enterprise Development: Learning from the Rural Context. Community Dev. J. 50, 478-493. https://doi.org/10.1093/cdj/bsu055

Muñoz, S.-A., Steinerowski, A.A., 2012. Socially Entrepreneurial Skills and Capabilities in a Rural Community Context, in: Farmer, J., Hilll, C., Muñoz, S.-A. (Eds.), Community Co-Production: Social Enterprise in Remote and Rural Communities. Edward Elgar, Cheltenham, UK, pp. 4774.

Nicholls, A., 2010. The Legitimacy of Social Entrepreneurship: Reflexive Isomorphism in a PreParadigmatic Field. Entrep. Theory Pract. 34, 611-633.

Pearce, J., 1993. At the Heart of the Community Economy: Community Enterprise in a Changing World. Calouste Gulbenkian Foundation, London.

Peredo, A.M., McLean, M., 2006. Social Entrepreneurship: A Critical Review of the Concept. J. World Bus. 41, 56-65. https://doi.org/10.1016/j.jwb.2005.10.007

Reynolds, S., 2008. Enterprise, Employment and Empowerment: The Social Firm Sector's Mission. Life Day 12, 27-31. https://doi.org/10.1108/13666282200800038

Roy, M.J., Hackett, M.T., 2017. Polanyi's 'Substantive Approach' to the Economy in Action? Conceptualising Social Enterprise as a Public Health 'Intervention.' Rev. Soc. Econ. 75, 89111. https://doi.org/10.1080/00346764.2016.1171383 
Roy, M.J., Sato, K., Calò, F., 2015. Further Limits to Institutional Isomorphism? Introducing the 'Neocontingency Approach' to the Field of Community-Led Social Ventures. Volunt. Int. J. Volunt. Nonprofit Organ. 26, 2536-2553. https://doi.org/10.1007/s11266-014-9529-z

Ruebottom, T., 2013. The Microstructures of Rhetorical Strategy in Social Entrepreneurship: Building Legitimacy Through Heroes and Villains. J. Bus. Ventur. 28, 98-116. https://doi.org/10.1016/j.jbusvent.2011.05.001

Scottish Government, 2016. Scotland's Social Enterprise Strategy 2016-2026.

Scottish Government, 2015. Community Empowerment (Scotland) Act.

Seanor, P., Meaton, J., 2008. Learning from Failure, Ambiguity and Trust in Social Enterprise. Soc. Enterp. J. 4, 24-40. https://doi.org/10.1108/17508610810877713

Smith, R., Bell, R., Watts, H., 2014. Personality Trait Differences Between Traditional and Social Entrepreneurs. Soc. Enterp. J. 10, 200-221. https://doi.org/10.1108/SEJ-08-2013-0033

Sonne, L., 2015. The Usefulness of Networks: A Study of Social Innovation in India, in: Nicholls, A., Simon, J., Gabriel, M., Whelan, C. (Eds.), New Frontiers in Social Innovation Research. Palgrave Macmillan, London, pp. 212-232.

Stake, R.E., 1995. The Art of Case Study Research. SAGE, London.

Stanton, J., 2014. The Big Society and Community Development: Neighbourhood Planning Under the Localism Act. Environ. Law Rev. 16, 262-276.

Steiner, A., Teasdale, S., 2016. The Playground of the Rich? Growing Social Business in the 21st Century. Soc. Enterp. J. 12, 201-216. https://doi.org/10.1108/SEJ-12-2015-0036

Steiner, A.A., Farmer, J., 2017. Engage, Participate, Empower: Modelling Power Transfer in Disadvantaged Rural Communities. Environ. Plan. C Polit. Space 239965441770173. https://doi.org/10.1177/2399654417701730

Teasdale, S., 2012. Negotiating Tensions: How Do Social Enterprises in the Homelessness Field Balance Social and Commercial Considerations? Hous. Stud. 27, 514-532. https://doi.org/10.1080/02673037.2012.677015

Teig, E., Amulya, J., Bardwell, L., Buchenau, M., Marshall, J.A., Litt, J.S., 2009. Collective efficacy in denver, colorado: strengthening neighborhoods and health through community gardens. Health Place 15, 1115-1122. https://doi.org/10.1016/j.healthplace.2009.06.003

Zahra, S.A., Gedajlovic, E., Neubaum, D.O., Shulman, J.M., 2009. A Typology of Social Entrepreneurs: Motives, Search Processes and Ethical Challenges. J. Bus. Ventur. 24, 519-532. https://doi.org/10.1016/j.jbusvent.2008.04.007 